\title{
Vaksin Covid-19: Perdebatan, Persepsi dan Pilihan
}

\author{
Lula Asri Octafia \\ Universitas Hasanuddin \\ lulaasrioctafia@gmail.com
}

\begin{abstract}
The current Covid-19 pandemic has had an impact on the political, economic, social, cultural, defense and security aspects as well as the welfare of the Indonesian people. Therefore, effective fast steps are needed to break the chain of the spread of Covid-19. One way to prevent transmission of this virus is through vaccination efforts. While the existing literature focuses more on State policies, public responses related to the effectiveness and safety of vaccines, as well as hoax news related to vaccines, the related literature on vaccines and the choice of vaccine if any is still very limited, this article fills that gap.
\end{abstract}

This qualitative research was carried out in Makassar, considering that Makassar is one of the metropolitan cities and many of its people has been vaccinated through Covid-19 vaccination programs. Data was collected using in-depth interview. Informants who participated in this study were people who had and had not carried out the Covid-19 vaccination. With a total of twenty-five people, they vary on the basis of age (between 18 and 29 years), sex (18 women and 7 men), and employment status (ten of them are students, employees, online shop owners, editors, musicians, painters, work odd jobs, and labor).

The results show that the emergence of the Covid-19 vaccine has become the subject of public debate, many agreed and not a few refused to be vaccinated. This debate is due to differences in perceptions regarding the definition of the Covid-19 vaccine and the benefits of the vaccine itself. In terms of what type of vacciness they are used, there are three types of vaccines that are popularly used by our participants in this study, namely Sinovac, Astra Zeneca, and Moderna. Apart from the debate about the level of efficacy of each vaccine, the choice of vaccine is related to the level of efficacy, side effects and availability of the vaccine itself. It is argued in this article that whatever the effect of a particular vaccine, as long as the side effect is balanced by its efficacy, then the effect is not an issue.

Keywords: Covid-19, pandemic, debate, perception, and the choice of vaccine.

\section{Pendahuluan}

Indonesia adalah salah satu Negara yang terjangkit virus corona pada awal tahun 2020. Kemunculan virus ini bermula di kota Wuhan, Tiongkok pada Desember 2019 lalu, sehingga diistilahkan Covid-19. Kemudian Covid-19 menyebar secara luas di Indonesia dan di berbagai Negara lainya. Covid-19 merupakan jenis virus yang memiliki sifat penyebaran secara contagious, yaitu virus yang menyebar secara cepat dalam sebuah jaringan. Apabila terdapat elemen yang saling terhubung dalam sebuah jaringan, maka virus ini dapat secara cepat menular. World Health Organization 
(WHO) telah menyatakan Covid-19 sebagai Global Pandemic dan Pemerintah telah menetapkan kedaruratan kesehatan masyarakat Covid-19 di Indonesia melalui Keputusan Presiden Nomor 11 Tahun 2020 tentang Penetapan Kedaruratan Kesehatan Masyarakat Corona Virus Disease 2019 (Covid-19), sehingga wajib dilakukan upaya penanggulangan sesuai dengan ketentuan peraturan perundangundangan (Kementerian Kesehatan Republik Indonesia 2021).

Penetapan kedaruratan kesehatan masyarakat Covid-19 dilakukan mengingat penyebaran Covid-19 yang bersifat luar biasa ditandai dengan jumlah kasus dan jumlah kematian yang telah meningkat dan meluas hingga lintas wilayah dan lintas negara dan berdampak pada aspek politik, ekonomi, sosial, budaya, pertahanan dan keamanan, serta kesejahteran masyarakat di Indonesia. Selain itu, atas pertimbangan penyebaran Covid-19 berdampak pada meningkatnya jumlah korban dan kerugian harta benda, meluasnya cakupan wilayah terdampak, serta menimbulkan implikasi pada aspek sosial ekonomi yang luas di Indonesia, maka pemerintah mengeluarkan Keputusan Presiden Nomor 12 Tahun 2020 tentang Penetapan Bencana Non-alam Penyebaran Corona Virus Disease 2019 (Covid19) Sebagai Bencana Nasional (Kementerian Kesehatan Republik Indonesia 2021).

Upaya penanggulangan Covid-19 terus dilakukan dengan berbagai strategi. Pesatnya penyebaran Covid-19 menyebabkan sekedar mematuhi protokol kesehatan saja tidak cukup. Diperlukan langkah cepat yang efektif dan dalam waktu singkat untuk meminimalisir dampak yang ditimbulkannya. Salah satu cara yang sangat mungkin untuk mencegah penyebaran virus ini adalah dengan mengembangkan vaksin. Ini karena vaksin tidak hanya melindungi mereka yang divaksinasi, tetapi juga melindungi masyarakat luas dengan mengurangi penyebaran penyakit dalam populasi.

Vaksinasi merupakan upaya kesehatan masyarakat yang dianggap paling efektif dan efisien dalam mencegah penularan penyakit yang berbahaya. Sejarah telah mencatat besarnya peranan vaksinasi dalam menyelamatkan masyarakat dari kesakitan, kecacatan, bahkan kematian akibat penyakit yang dapat dicegah dengan vaksinasi (PD3V). Dalam upaya penanggulangan pandemi Covid19, vaksinasi Covid-19 bertujuan untuk meminimalisir penyebaran Covid-19, menurunkan angka positif dan kematian akibat Covid-19, mencapai kekebalan kelompok (herd imunity) dan melindungi masyarakat dari Covid19 agar tetap produktif secara sosial dan ekonomi. Upaya vaksinasi Covid-19 telah dilakukan oleh berbagai negara, termasuk Indonesia (Kementerian Kesehatan Republik Indonesia, 2021). ${ }^{1}$

Namun, permasalahan yang dihadapi Indonesia sejak munculnya wacana tenatng vaksinasi adalah masih banyak masyarakat yang menolak vaksinasi. Salah satu faktor yang menyebabkan masyarakat enggan melaksanakan vaksinasi adalah menyebarnya hoaks bahwa vaksin itu berbahaya bagi kesehatan manusia, vaksin mengandung minyak babi, vaksin memiliki alat pelacak (chip), vaksin mengandung efek samping yang sangat tinggi, sehingga menyebabkan kematian. Hoaks semacam ini memengaruhi masyarakat dan membuat mereka takut untuk divaksin. Pemerintah Indonesia juga mendapat banyak kritikan atas penanganan Covid-19 dan ini berlangsung hingga ke tahap vaksinasi Covid-19.

\footnotetext{
${ }^{1}$ https://alitamir.files.wordpress.com/2021/06/kmkno.-hk.01.07-menkes-4638-2021-ttg-juknispelaksanaan-vaksinasi-dalam-rangkapenanggulangan-pandemi-covid-19-sign.pdf, diakses tanggal 4 Oktober 2021.
} 
Ini karena kebijakan yang diambil ini terkesan tergesa-gesa tanpa disertai pembuktian empiris akan kegunaan vaksin. Terkesan pula bahwa ada niatan mencari keuntungan ekonomis dengan memaksakan penggunaan produk ini dengan penggunaan tangan kekuasaan dan kepentingan negara (Sukmana dkk. 2021:412). Menurut Fatimah dkk. (2021) dengan diselenggarakanya sosialisasi mengenai vaksin Covid-19, ini akan memberikan pemahaman kepada masyarakat tentang pentingnya vaksinasi. Dengan demikian, tidak ada lagi keraguan dalam diri individu dalam penerimaan vaksin Covid-19.

Meskipun demikian, tidak sedikit masyarakat merespon secara positif terhadap program vaksinasi. Dengan berfokus pada respon masyarakat terhadap vaksinasi dengan memanfaatkan data dari media sosial Twitter, Rachman dan Pramana (2020) menunjukkan bahwa masyarakat lebih banyak memberikan respon positif terhadap wacana tersebut (30\%) dibandingkan dengan respon negatifnya (26\%). Kata-kata bersentimen yang paling sering muncul juga mengindikasikan lebih banyak kata yang bersentimen positif dibandingkan dengan kata yang bersentimen negatif.

Program vaksinasi ini terlaksana setelah pada tanggal 11 Januari 2021, Badan POM mengeluarkan persetujuan penggunaan darurat (EUA) untuk vaksin dan dikeluarkannya fatwa halal oleh Majelis Ulama Indonesia. Tahap pertama vaksinasi Covid-19 yang menyasar pada tenaga kesehatan telah mencapai lebih dari $70 \%$ dan belum ditemukan kejadian ikutan pasca imunisasi (KIPI) yang serius (Fitriani dkk. 2021:45-46).

Namun pengadaan vaksin Covid-19 tidak secepat penyebarannya. Vaksin Covid-19 yang bertujuan untuk mencegah penyakit yang menular dan untuk memeroleh respon imun yang kuat secara umum lebih aman dan lebih mudah diperoleh (Makmun dan Hazhiyah 2020). Ini menunjukkan bahwa vaksin Covid-19 saat ini adalah langkah terbaik untuk menghentikan pandemi yang melanda dunia, termasuk Indonesia. Menurut Masnun dkk. (2021), pandemi Covid-19 tidak hanya berdampak dalam bidang ekonomi dan pendidikan, tetapi juga berperan dalam bidang hukum. Aspek hukum dapat dijadikan sebagai dasar intervensi negara dalam melindungi vaksin Covid-19 sebagai karya intelektual manusia.

World Health Organization (WHO) menargetkan setiap negara untuk memvaksinasi paling sedikit $40 \%$ dari populasi pada akhir tahun 2021, dan 70\% pada pertengahan 2022. Dengan cakupan vaksinasi dosis pertama sebesar 62,5 persen dan dosis kedua yang mencapai 40,4 persen per 14 November 2021, maka Indonesia telah melampaui target yang telah ditetapkan oleh WHO. Data dari Kemenkes per tanggal 15 November 2021 menunjukkan bahwa cakupan vaksinasi di Indonesia telah mencapai 215,17 juta dosis vaksin Covid-19. Sekitar 130,62 juta orang $(62,72)$ dari 208,2 juta sasaran telah menerima dosis pertama dan lebih dari 84,55 juta (40,60\%) sudah mendapatkan dosis kedua. Untuk vaksinasi dosis ketiga (booster) bagi tenaga kesehatan telah diberikan kepada sekitar 1,19 juta orang $(81,11 \%)$ dari target sasaran. ${ }^{2}$ Dengan capaian seperti itu, Menteri Keuangan Sri Mulyani mengumumkan (23 November 2021), bahwa Indonesia menduduki peringkat kelima dunia, ${ }^{3}$ setelah Cina, India, Amerika Serikat, dan Brazil. ${ }^{4}$

\footnotetext{
${ }^{2}$ https://setkab.go.id/cakupan-vaksinasi-lengkap-diindonesia-lampaui-target-who/, diakses tanggal 15 November 2021.

${ }^{3}$ https://investor.id/business/271869/menkeuindonesia-peringkat-kelima-dunia-vaksinasiterbanyak, diakses tanggal 25 November 2021. ${ }^{4}$ https://www.liputan6.com/global/read/4675981/vaks inasi-covid-19-di-indonesia-peringkat-5-duniakalahkan-jepang-dan-inggris, diakses tanggal 28 November 2021.
} 
Di tengah maraknya vaksinasi yang dicanangkan pemerintah, timbul pro-kontra terkait itu. Jika merujuk pada perdebatan di Twitter tentang vaksin Covid-19 umumnya aspek perdebatan dititikberatkan keterburuburuan, sertifikasi halal vaksin, dan keraguan masyarakat terkait dengan kualitas vaksin (Rachman dan Pramana 2020). Kajian Rahayu dan Sensusiyati (2021), yang berfokus pada berita hoaks terkait vaksin, menunjukkan bahwa berita hoaks yang beredar dalam berita-berita online diklasifikasikan atas hoaks terkait kandungan, efek samping, dan penolakan vaksin. Dalam survey cross sectional secara online melalui Whatsapp dengan sampel sebesar 399 responden yang dilakukan oleh Puteri dkk. (2021) menunjukkan bahwa meskipun $81,2 \%$ responden menyatakan kesediaannya untuk divaksin, $48,1 \%$ responden mengalami kecemasan terhadap vaksin. Jika merujuk pada studi yang dilakukan oleh Kholidiyah dkk. (2021), maka ada hubungan yang signifikan antara persepsi masyarakat tentang vaksin Covid-19 dan kecemasan mereka saat akan menjalani vaksinasi tersebut.

Studi Nugroho dan Hidayat (2021), yang berfokus pada efektivitas dan keamanan vaksin, mengindikasikan bahwa berdasarkan uji klinis, semua jenis vaksin Covid-19 menunjukkan imunogenisitas yang menjanjikan dengan tingkat efektivitas perlindungan dan keamanan yang dapat diterima. Jika membandingkan antara dosis pertama dan kedua pada semua jenis vaksin, maka yang dosis kedua memberikan respon imun yang lebih kuat. Vaksin Pfizer memiliki tingkat efektivitas dan kemanan hingga 94,6\% tanpa efek samping yang serius.

Meskipun literatur yang ada telah mencakupkan tentang perdebatan terkait vaksin (di media sosial), kontribusi baru dalam penelitian ini adalah bagaimana persepsi memengaruhi perdebatan dan bagaimana orang menjatuhkan pilihannya pada jenis vaksin yang digunakan. Pembahasan dalam artikel ini dibagi menjadi tiga bagian. Bagian pertama mengeksplorasi persepsi tentang vaksin. Bagian kedua, mendiskusikan vaksin dan perdebatannya. Bagian ketiga, mendemonstrasikan pilihan jenis vaksin dan alasan yang mendasari pilihan tersebut.

\section{Metode Penelitian}

Penelitian ini dilakukan di kota Makassar antara bulan September dan Oktober dengan menggunakan pendekatan kualitatif. Kota Makassar dipilih sebagai lokasi penelitian karena merupakan kota dengan jumlah masyarakat yang melaksanakan vaksinasi terbanyak di Sulawesi Selatan. Merujuk pada data vaksinasi yang dihimpun oleh Dinas Kesehatan kota Makassar per tanggal 1 September 2021, capaian vaksinasi Covid-19 di kota Makassar telah mencapai 50,06\% untuk dosis pertama atau menyasar 551.879 jumlah warga Makassar yang telah divaksin dari total sasaran vaksin 1.102.330 warga Makassar. Sementara yang telah mendapatkan vaksin penuh atau mendapat dua dosis mencapai angka 31,77 \% atau 350.247 warga Makassar. ${ }^{5}$

Informan dalam penelitian ini berjumlah 25 orang yang terdiri atas 18 orang perempuan dan tujuh orang laki-laki. Dari 25 informan, 19 di antaranya pro terhadap vaksin Covid-19 karena melihat dari sisi manfaatnya dan membantu pemerintah mencapai herd immunity, sedangkan enam informan lainnya kontra terhadap program vaksinasi Covid-19 karena percaya pada isu-isu negatif yang beredar luas di masyarakat (lihat Tabel 1).

\footnotetext{
${ }^{5}$ https://upeks.co.id/2021/09/vaksinasi-covid-19-dikota-makassar-capai-50/, diakses tanggal 16 November 2021.
} 


\begin{tabular}{|c|c|c|c|c|c|}
\hline & \multicolumn{5}{|c|}{ Table 1. Informan penelitian } \\
\hline No. & Nama & Jenis kelamin & Umur & Pekerjaan/Status & Pro-Kontra \\
\hline 1. & Aletta & $P$ & 19 & Mahasiswi & Kontra \\
\hline 2. & Ingga & $P$ & 20 & Mahasiswi & Pro \\
\hline 3. & Unna & $P$ & 20 & Mahasiswi & Kontra \\
\hline 4. & Lisa & $P$ & 20 & Mahasiswi & Pro \\
\hline 5. & Nur & $P$ & 21 & Mahasiswi & Pro \\
\hline 6. & Mawar & $P$ & 21 & Mahasiswi & Pro \\
\hline 7. & Nila & $P$ & 21 & Mahasiswi & Pro \\
\hline 8. & Upin & $\bar{L}$ & 21 & Mahasiswa & Pro \\
\hline 9. & Ipin & $\mathrm{L}$ & 21 & Mahasiswa & Pro \\
\hline 10. & Farah Y. & $P$ & 22 & Mahasiswi & Pro \\
\hline 11. & Khadijah & $P$ & 21 & Karyawan & Pro \\
\hline 12. & Inan & $\bar{L}$ & 22 & Karyawan Restoran & Pro \\
\hline 13. & Kevin & $L$ & 23 & Karyawan & Pro \\
\hline 14. & Anita & $P$ & 24 & Karyawan & Pro \\
\hline 15. & Hamzah & $L$ & 29 & Karyawan & Kontra \\
\hline 16. & Fatimah & $P$ & 18 & Online Shop & Pro \\
\hline 17. & Intan & $P$ & 20 & Online Shop & Pro \\
\hline 18. & Memei & $P$ & 29 & Online Shop & Pro \\
\hline 19. & Abian & $L$ & 21 & Editor & Pro \\
\hline 20. & Selin & $P$ & 21 & Musisi & Kontra \\
\hline 21. & Kintan & $P$ & 21 & Musisi & Pro \\
\hline 22. & Ilvi & $P$ & 21 & Pelukis & Pro \\
\hline 23. & Susanti & $P$ & 22 & Serabutan & Kontra \\
\hline 24. & Markonah & $P$ & 24 & Serabutan & Pro \\
\hline 25. & Ali & $\mathrm{L}$ & 23 & Buruh & Kontra \\
\hline
\end{tabular}

Data dikumpulkan dengan mengunakan teknik wawancara mendalam (in-depth interview). Topik-topik wawancara meliputi vaksin dan perdebatanya, serta manfaat vaksin dan pilihan jenis vaksin Covid-19. Wawancara ini dilakukan dengan dua cara, yakni wawancara tatap muka (7 orang) di rumah informan dengan mematuhi protokol kesehatan dan wawancara via chatting di media sosial (Whatsapp dan Instagram, 18 orang).

$$
\text { Analisis dilakukan dengan }
$$
mentranskripsikan data yang diperoleh dari hasil wawancara mendalam. Data ini kemudian dikelompokkan berdasarkan tema yang muncul seperti, pro-kontra terhadap vaksinasi, persepsi tentang vaksin dan jenis pilihan vaksin Covid-19. Setelah data dikelompok berdasarkan tema tersebut, selanjutnya data di narasikan.

Dalam penelitian ini, kesediaan informan diperoleh melalui chatting personal pada aplikasi Whatsapp dengan terlebih dahulu menjelaskan identitas peneliti, topik penelitian, maksud dan tujuan penelitian, serta topik-topik pertanyaan yang akan dipertanyakan. Jika 
mereka setuju untuk berpartisipasi dalam penelitian ini, maka mereka dimintai kesedian untuk diwawancarai, baik secara langsung (face to face), maupun melalui media online (Whastapp dan Instagram). Identitas informan dijaga kerahasiaanya dan diproteksi melalui penggunaan nama samaran, sebagaimana yang diinginkan oleh informan yang berpartisipasi dalam penelitian ini.

\section{Persepsi Tentang Vaksin}

Menurut Mulyana (2007:179), persepsi adalah proses internal yang memungkinkan seseorang memilih, mengorganisasikan dan menafsirkan rangsangan dari lingkungannya, dan proses tersebut memengaruhi perilakunya. Dalam kaitan dengan vaksin Covid-19, temuan penelitian ini menunjukkan bahwa persepsi masyarakat tentang vaksin Covid-19 mencakup bagaimana mereka mendefinisikan vaksin Covid-19 dan apa manfaat dari vaksin Covid-19.

\section{Mendefinisikan Vaksin Covid-19}

Vaksin adalah produk biologi yang berisi antigen yang bila diberikan kepada seseorang akan menimbulkan kekebalan spesifik secara aktif terhadap penyakit tertentu. Produk/zat yang dimasukkan (suntikan/oral) ke dalam tubuh untuk menstimulasi sistem imun tubuh. ${ }^{6}$

Vaksinasi Covid-19 merupakan salah satu upaya pemerintah Indonesia dalam menangani masalah Covid-19. Vaksinasi Covid19 bertujuan untuk menciptakan kekebalan kelompok (herd immunity) agar masyarakat dapat produktif dalam menjalankan aktivitas kesehariannya di tengah pandemi Covid-19. Vaksin dikenal sebagai pembentuk imunitas untuk mencegah penularan Covid-19. Para

\footnotetext{
${ }^{6}$ https://mekarsaripacet.desa.id/artikel/2021/6/24/cari-tahu-apa-ituvaksin-dan-vaksinasi, diakses tanggal 21 Agustus 2021.
}

informan mendefinsikan vaksin dengan mengasosiasikannya dengan zat kimia yang digunakan untuk membentuk kekebalan tubuh seseorang.

Abian (21 tahun) menyatakan bahwa vaksin Covid-19 merupakan sejenis obat yang dibuat oleh peneliti di bidang farmasi untuk mengobati penyakit yang menular. Bagi Ali (23 tahun) vaksin Covid-19 merupakan produk biologi yang diciptakan dari virus yang telah dilemahkan untuk meningkatkan sistem kekebalan tubuh manusia agar terhindar dari penyakit menular. Nur (21 tahun) berpendapat vaksin Covid-19 adalah mikroorganisme pembentuk antibodi atau imunitas dalam tubuh.

Menurut Anita (24 tahun), vaksin Covid19 merupakan sebuah cairan kimia yang disuntikkan kedalam tubuh agar terhindar dari suatu penyakit. Program vaksinasi ini terbukti dapat mengurangi resiko penularan Covid-19 pada tubuh dan membantu pemerintah untuk mengurangi penyebaran Covid-19 di Indonesia.

Per tanggal 12 Oktober 2021 tercatat jumlah vaksinasi dosis pertama meningkat hingga angka 1.040.519 jiwa dan untuk dosis kedua mencapai 798.380 jiwa. Peningkatan jumlah vaksinasi berbanding terbalik dengan jumlah kasus aktif yang menurun hingga 916 jiwa. $^{7}$

Vaksin Covid-19 dipersepsikan oleh Intan (20 tahun) sebagai semacam obat yang mengandung zat/senyawa yang berfungsi untuk meningkatkan kekebalan tubuh agar terlindung dari virus. Program vaksinasi dianggapnya sebagai langkah jitu pemerintah untuk menghentikan pandemi Covid-19. Hal serupa dikemukakan oleh Lisa (20 tahun), bahwa vaksin Covid-19 merupakan sebuah senyawa/zat yang disuntikkan ke dalam tubuh untuk membentuk

\footnotetext{
${ }^{7}$ https://covid19.go.id/berita/data-vaksinasi-covid-19update-12-oktober-2021 diakses tanggal 25 November 2021
} 
imun manusia. Dengan divaksin Lisa (20 tahun) merasa lebih aman jika bepergian dan terhindar dari Covid-19.

\section{Manfaat Vaksin}

Pemberian vaksin Covid-19 memiliki banyak manfaat, salah satunya adalah untuk meningkatkan kekebalan tubuh dari paparan Covid-19 dan mencegah mutasi baru dari Covid19. ${ }^{8}$ Kementrian Kesehatan RI menyatakan, bahwa vaksin Covid-19 bermanfaat untuk memberikan perlindungan pada tubuh agar tidak terpapar Covid-19 dengan cara menimbulkan atau merangsang imunitas spesifik dalam tubuh dengan penyediaan vaksin (Kemenkes 2021).

Ada berbagai persepsi masyarakat dalam kaitan dengan manfaat vaksin Covid-19. Abian (21 tahun), misalnya, mengungkapkan bahwa dengan diadakannya vaksinasi, ini dapat mengurangi tingkat atau resiko penularan Covid-19 secara lebih meluas. Vaksinasi bermanfaat tidak saja untuk melindungi diri sendiri, tapi juga orang lain.

Menurut Nur (21 tahun) dengan melaksanakan vaksinasi ini, ia turut andil dalam membantu pemerintah untuk meminimalisir penyebaran Covid-19. Dengan divaksin Covid19, menurut Farah (22 tahun), kita tidak saja terhindar dari Covid-19, tapi juga dengan vaksinasi orang menjadi semakin tidak was-was menghadapi Covid-19 dan ini turut menjaga stabilitas imun seseorang. Vaksin juga bisa melindungi orang disekitar orang yang tidak bisa divaksin karena mengidap penyakit tertentu dan

${ }^{8}$ https://www.google.com/search?q=apa+itu+vaksin\& client=safari\&rls=en\&ei=1-

S1YYbPE9b7z7sP3dWL2Aw\&ved=0ahUKEwjG9pe 6m970AhXW_XMBHd3qAssQ4dUDCA0\&uact=5\& oq=apa+itu+vaksin\&gs_lcp=Cgdnd3Mtd216EAxKB AhBGABKBAhGGABQAFgAYABoAHAAeACAA QCIAQCSAQCYAQA\&sclient=gws-wiz, diakses tanggal 28 November 2021. dengan demikian ini berkontribusi terhadap upaya meminimalisir penyebaran Covid-19. Hal serupa diungkapkan oleh Susanti (22 tahun), bahwa dengan vaksinasi ini kekebalan tubuh terbentuk dan membuat orang menjadi lebih percaya diri untuk beraktivitas, lebih potensil terhindar dari penularan Covid-19, meski tetap harus memerhatikan protokol kesehatan.

Nila (22 tahun) menyatakan manfaat dari vaksin itu sendiri adalah untuk membentuk sistem kekebalan dalam tubuh dan mencegah terinfeksi Covid-19. Bagi Inan (22 tahun) manfaat dari vaksin adalah untuk mengurangi gejala dari Covid-19 dan dapat memicu sistem imun tubuh untuk melawan virus corona. Lisa (20 tahun) mengungkapkan, bahwa vaksin bisa mencegah terjadinya gejala yang berat dan komplikasi pada tubuh. Sedangkan menurut Ingga (20 tahun) vaksin sebagai pendorong terbentuknya kekebalan kelompok (herd immunity.

Apapun definisi dan manfaat yang dikemukakan tentang vaksin Covid-19, ini dapat memberikan dampak positif. Jika vaksin dipersepsikan dalam kaitan dengan bahan dasar dan tujuannya; maka manfaat vaksin diassosiasikan dengan perlindungan tidak saja pada diri sendiri, tapi juga orang lain, serta sebagai kontribusi terhadap pemerintah dalam program vaksinasi untuk memutus mata rantai penyebaran Covid-19.

\section{Vaksin dan Perdebatannya di Indonesia}

Vaksin adalah produk biologi imunogenik (menimbulkan respon imun) berupa mikroorganisme utuh atau bagian dari mikroorganisme yang tidak berbahaya. Secara umum vaksin terbagi menjadi 2 jenis yaitu vaksin preventif dan vaksin terapetik. Vaksin preventif ditujukan untuk pencegahan suatu infeksi, sedangkan vaksin terapetik ditujukan untuk pengobatan suatu penyakit misalnya 
kanker. Vaksin preventif diberikan pada individu sehat dengan tujuan merangsang terbentuknya antibodi sebagai bentuk kekebalan tubuh untuk mencegah timbulnya infeksi bakteri atau virus tertentu. ${ }^{9}$

Vaksinasi Covid-19 merupakan salah satu upaya pemerintah Indonesia dalam menangani pandemi Covid-19. Ini bertujuan untuk menciptakan kekebalan kelompok (herd immunity) agar masyarakat menjadi lebih produktif dalam menjalankan aktivitas kesehariannya. Namun, kemunculan vaksin Covid-19 di Indonesia menimbulkan pro-kontra. Di satu sisi ada yang menyetujui untuk divaksin; di sisi lain, tidak sedikit yang menolak untuk divaksinasi.

\section{Setuju Divaksin}

Program vaksinasi bertujuan untuk membentuk kekebalan kelompok (herd immunity) dan meminimalisir penyebaran Covid-19. Menurut Andriadi, dkk. (2021:102), vaksin memberikan manfaat penting kepada semua orang. Adapun hal yang mendorong individu untuk melakukan vaksinasi cukup bervariasi, yakni karena melihat dari sisi manfaat, karena ingin membantu pemerintah untuk mencapai herd immunity, dan karena percaya bahwa program vaksinasi yang dicanangkan pemerintah sebagai bentuk perlindungan negara terhadap rakyatnya.

Ada yang melihat dari sisi manfaatnya. Abian (21 tahun), misalnya, bersedia divaksin karena ia menganggap bahwa vaksin Covid-19 dapat menghentikan atau paling tidak meminimalisir penularan Covid-19. Farah (22 tahun) juga menyatakan persetujuannya untuk divaksin karena ia menganggap vaksin dapat meningkatkan imunitas tubuh dan dapat mencegah terjangkitnya Covid-19.

\footnotetext{
${ }^{9}$ https://hmpf.fa.itb.ac.id/2020/09/11/vaksin-dancovid-19/, diakses tanggal 28 Oktober 2021.
}

Yang lainnya menyetujui untuk divaksinasi tidak saja karena manfaat vaksin itu sendiri tapi juga untuk membantu pemerintah mencapai herd immunity. Ilvi (21 tahun) menyetujui untuk divaksin tidak saja untuk kepentingan melindungi diri dari Covid-19, tetapi ia juga ingin mewujudkan program pemerintah untuk membentuk herd immunity (kekebalan kelompok). Inan (22 tahun) mau divaksin karena mendukung rencana pemerintah untuk mengurangi efek dari Covid19. Awalnya ia memang mau divaksin karena kewajiban dari tempat kerja, tapi ia juga ingin berkontribusi terhadap program pemerintah untuk membentuk herd immunity. Khadijah (21 tahun) adalah contoh kasus yang lain yang bersedia divaksin karena adanya kesadaran dalam diri sendiri bahwa penyebaran Covid-19 semakin luas dan sebagai mahasiswi yang memiliki banyak kegiatan di luar rumah, ia merasa perlu untuk melindungi diri sekaligus membantu pemerintah dalam mencapai herd immunity. Ini artinya bahwa mereka tidak hanya memikirkan proteksi atas dirinya sendiri, tapi juga untuk proteksi dan keselamatan orang banyak.

Ada pula yang berpendapat dalam kaitan dengan sanksi pemerintah, seperti yang dikemukakan oleh Fatimah (18 tahun), bahwa selain sebagai kewajiban bagi seluruh rakyat Indonesia untuk divaksin, ia juga takut pada sanksi dari pemerintah jika ia tidak divaksin, meskipun ia sendiri tidak memahami bentuk sangsi yang akan diberikan oleh pemerintah terkait itu. Ini menunjukkan kepatuhan Fatimah terhadap pemerintah sebagai warga negara yang baik.

Ironisnya, ada yang awalnya tidak mau divaksin karena percaya akan rumor yang berkembang di masyarakat, tapi kemudian menyetujui untuk divaksin karena bukti vaksin merupakan prasyarat untuk mengakses atau 
mengurus banyak hal. Kevin (23 tahun), misalnya, yang awalnya menolak untuk divaksinasi karena adanya rumor yang beredar bahwa setelah seseorang divaksin, ia akan berpenyakitan, berubah menjadi zombie, bahkan mati secara perlahan. Namun, ia akhirnya bersedia divaksin karena ia membutuhkan kartu vaksin sebagai prasyarat untuk mengurus berbagai kartu lainnya, seperti KTP, SIM, SKCK dan kartu keluarga. Ini serupa dengan Kintan (21 tahun) yang juga awalnya tidak mau divaksin karena ada rumor di media sosial dan di lingkungan sekitarnya bahwa setelah divaksin, seseorang akan sakit parah bahkan sampai meninggal dunia. Padahal kematian yang terjadi belum tentu disebabkan oleh vaksin tersebut, sebagaimana pada tiga kasus yang terjadi pada orang yang meninggal pasca divaksin. Prof. Hindra, ketua Komnas KIPI, menjelaskan bahwa meninggalnya mereka dipastikan tidak ada hubungannya dengan vaksin. ${ }^{10}$

Ini membuatnya penasaran dan membuatnya berubah fikiran untuk bersedia divaksin. Ternyata setelah divaksin ia tidak merasakan gejala apapun. Hal serupa terjadi pada Markonah (24 tahun) yang juga menyetujui untuk divaksin karena ia membutuhkan sertifikat vaksin. Waktu itu ia mendapatkan informasi bahwa jika seseorang telah divaksinasi, maka ia akan lebih leluasa untuk bepergian, baik di dalam kota maupun ke luar kota.

Ada yang berpendapat bahwa program vaksinasi sebagai bentuk perlindungan negara terhadap masyarakat. Lisa (20 tahun), misalnya, sangat setuju dengan program vaksinasi karena tidak percaya dengan berita-berita negatif tentang vaksin yang beredar di media sosial. la percaya bahwa pemerintah tidak akan

${ }^{10}$ https://farmasi.ugm.ac.id/id/archives/4888, diakses tanggal 28 November 2021. mencelakakan masyarakatnya melalui program vaksinasi, justru sebagai bentuk perlindungan negara terhadap masyarakat. Ini berkelindan dengan pendapat Mawar (21 tahun), bahwa vaksinasi adalah salah satu upaya pemerintah untuk melindungi masyarakat dari penularan Covid-19, sehingga ia tidak ragu-ragu untuk divaksin.

\section{Menolak Divaksin}

Vaksinasi merupakan salah satu program pemerintah untuk menekan angka penularan Covid-19. Namun, masih ada yang menolak/tidak setuju dengan adanya vaksinasi dan kurang percaya terhadap vaksin Covid-19. Ada sejumlah alasan kenapa orang menolak divaksinasi, yakni karena percaya pada isu-isu tentang vaksin, karena menganggap vaksin bukan solusi untuk mengatasi penularan Covid19, dan karena tidak yakin terhadap keampuhan vaksin Covid-19.

Ali (23 tahun), misalnya, yang sebenarnya mau divaksin tapi ia membaca dan mendengar terlalu banyak isu yang beredar tentang vaksin di media sosial dan lingkungan sekitarnya, bahwa jika seseorang divaksin, maka ia akan mengalami kelumpuhan atau akan meninggal dunia setelahnya. Ini membuatnya menjadi ragu untuk divaksinasi. Padahal sejauh inibelum ada hasil penelitian yang menunjukkan bahwa vaksin menjadi penyebab kematian. Selain itu, ia juga secara nyata melihat berbagai ke jadian di sekitarnya, banyak orang yang terinfeksi Covid-19 walaupun telah divaksinasi. la juga dibuat bingung oleh adanya berita di internet bahwa pada awal dicanangkannya vaksinasi, pemerintah tidak mewajibkan masyarakat untuk divaksinasi. Namun, sekarang seakan-akan vaksinasi dipaksakan kepada masyarakat. Ini dapat dilihat dari berbagai aturan yang mengikuti vaksinasi tersebut. Jika seseorang tidak divaksinasi, maka 
yang bersangkutan tidak dapat berkunjung ke tempat umum, tidak dapat melakukan perjalanan via pesawat terbang, tidak dapat mengurus administrasi kependudukan, dll. Hal serupa dialami oleh Alettah (19 tahun) yang sampai sekarang masih ragu dengan adanya vaksin Covid-19 karena dia masih bingung melihat apa yang telah terjadi di lingkungan sekitarnya dimana ada orang yang mengalami kelumpuhan, berpenyakitan, bahkan meninggal. Sebaliknya, ada juga orang yang tanpa efek samping setelah divaksin. Selain itu, orang tuanya juga tidak memperbolehkan dirinya untuk vaksin.

Selin (21 tahun) menganggap vaksin Covid-19 bukan satu-satunya cara untuk menangani penularan Covid-19 karena masih banyak cara lain untuk meminimalisir Covid-19, seperti menggunakan masker saat bepergian, menjaga jarak, menjaga kebersihan, menghindari kerumunan dan lain-lain. la sendiri tidak mau divaksin karena percaya dengan berita-berita negatif yang beredar tentang vaksin yang beredar di media sosial dan di lingkungan sekitarnya bahwa vaksin itu berbahaya, dosisnya sangat tinggi dan takut terhadap jarum suntik.

Penolakan terhadap vaksinasi juga dikemukakan oleh Hamzah (29 tahun) karena iya meyakini sistem imunnya sendiri dan tidak meyakini tentang keampuhan vaksin Covid-19. Hamzah belum percaya akan manfaat dari vaksin itu sendiri dan belum percaya kepada pemerintah karena adanya informasi negatif yang beredar di media sosial tentang vaksin. Ini beririsan dengan pendapat Susanti (22 tahun) yang meyakini kebenaran isu-isu tentang vaksin. Oleh karenanya, ia menolak untuk divaksin, salah satunya karena ia takut mati perlahan setelah divaksin Covid-19, sebagaimana informasi yang ia dapatkan melalui mediamedia sosial.
Melihat apa yang telah terjadi di sekitarnya, Unna (21 tahun) menolak untuk divaksin karena tetangganya meninggal dunia setelah divaksinasi. la sangat takut dan trauma terhadap kejadian tersebut dan tidak mau keluar rumah untuk melakukan aktivitas rutinnya. Jika ia melihat seseorang mengenakan pakaian seperti petugas kesehatan, maka ia langsung masuk kedalam rumah untuk bersembunyi karena iya mengira akan divaksin.

Umumnya, penolakan terhadap program vaksinasi karena mereka memeroleh informasi yang negatif tentang vaksin sehingga ini "membelah" mereka dalam kaitan dengan apakah mereka mau atau tidak untuk divaksinasi.

\section{Pilihan Jenis Vaksin}

Ada berbagai jenis vaksin Covid-19, yaitu Sinovac, Astra Zeneca, Sinopharm, Moderna, Pfizer, Novavax, Janssen, Biofarma, Cansino, dan Zifivax. ${ }^{11} \mathrm{Di}$ Indonesia, vaksin yang digunakan dalam program vaksinasi Covid-19 adalah Sinovac, Biofarma, Moderna, Pfizer, Astra Zeneca dan Sinopharm. Vaksin yang didatangkan dari beberapa Negara, seperti Cina, Jerman, dan Inggris ini beredar di Indonesia hingga periode tahun 2022. Namun, tiga jenis vaksin yang paling populer digunakan di Indonesia adalah Sinovac, Moderna dan Astra Zeneca. Temuan penelitian ini menunjukkan, bahwa pilihan dan penolakan vaksin dikaitkan dengan: tingkat efikasi dan efek sampingnya serta ketersediaan vaksin.

\section{Sinovac}

Vaksin Sinovac atau CoronaVac adalah vaksin Covid-19 pertama di Indonesia yang mendapat izin penggunaan darurat (EUA) dari BPOM pada

\footnotetext{
${ }^{11} \mathrm{https}: / /$ news.detik.com/berita/d-5762537/adaberapa-jenis-vaksin-covid-di-indonesia-inidaftarnya/2, diakses tanggal 6 November 2021.
} 
hari Senin, 11 Januari 2021.12 Vaksin Sinovac dibuat dengan metode mematikan virus (inactivated virus), sehingga vaksin ini tidak mengandung virus hidup dan tidak bisa bereplikasi. Virus corona yang sudah mati ini kemudian dicampur dengan senyawa berbasis aluminium yang disebut adjuvan. Senyawa ini berfungsi merangsang sistem kekebalan dan meningkatkan respons terhadap vaksin. ${ }^{13}$ Kenapa Indonesia memilih Sinovac? Direktur Utama Bio Farma, Honesti Basyir, menjelaskan bahwa dasar pemilihan vaksin Covid-19 harus memenuhi beberapa aspek, yakni keamanan, cepat, dan mandiri. Dari segi keamanan, vaksin ini telah melalui serangkaian pengujian (praklinis, uji klinis tahap satu, dua, dan tiga). Ini karena vaksin dari China ini telah dinyatakan sebagai salah satu vaksin yang telah mendapatkan pengakuan dari segi mutu oleh WHO. Dari segi kecepatan, di antara 10 kandidat vaksin, Sinovac termasuk yang tercepat masuk uji klinis tahap tiga. Sementara dari segi kemandirian, dengan begitu banyaknya vaksin yang dibutuhkan dan ini tidak dapat terpenuhi jika hanya mengharapkan dari luar, maka PT. Bio Farma melakukan transfer teknologi dan mendukung kemandirian bangsa dalam memproduksi vaksin Covid-19 sebagai strategi dalam penyediaan vaksin Covid-19 bagi masyarakat Indonesia. ${ }^{14}$ Vaksin Sinovac memang vaksin pertama dan direkomendasikan untuk digunakan di Indonesia dengan tingkat efikasi $65,3 \%$, yang efek sampingnya relatif lebih

${ }^{12}$ https://newssetup.kontan.co.id/news/ada-9-jenisvaksin-covid-19-yang-digunakan-di-indonesia-apasaja-efek-sampingnya?page=all, diakses tanggal 25 November 2021.

${ }^{13}$ https://homecare24.id/2021/09/02/perbedaanvaksin-sinovac-astrazeneca-pfizer-moderna/, diakses tanggal 25 November 2021.

${ }^{14}$ https://ekonomi.bisnis.com/read/20201015/257/130 5240/kebutuhan-sangat-besar-ini-strategikemandirian-pengadaan-vaksin-19, diakses tanggal 25 November 2021. ringan dibandingkan dengan vaksin jenis lain, seperti nyeri, iritasi, pembengkakan, nyeri otot, dan demam.

Namun, kini vaksin Sinovac bukan satusatunya vaksin yang digunakan di Indonesia. Tapi kenapa Sinovac jadi pilihan? Temuan penelitian ini menunjukkan bahwa vaksin Sinovac dijadikan pilihan karena dua hal, yaitu: karena efek sampingnya yang relatif ringan dibandingkan vaksin yang lain dan karena ketersediaannya.

Ilvi (21 tahun), misalnya, memilih jenis vaksin Sinovac karena ia mendapatkan informasi dari sosialisasi vaksin di sekitar tempat tinggalnya yang dilakukan oleh Dinas Kesehatan bahwa efek samping dari jenis vaksin Sinovac lebih rendah dibandingkan jenis vaksin lain. Ingga (20 tahun) awalnya ingin memilih jenis vaksin Moderna karena menurut informasi yang diperoleh dari media sosial vaksin jenis ini lebih kuat daya tangkalnya dibandingkan jenis Sinovac. Akan tetapi, Ingga menyadari bahwa fisiknya sangat lemah dan efek samping dari Moderna lebih tinggi dari pada Sinovac. Pada akhirnya Ingga memilih jenis vaksin Sinovac, meski ini bukan jenis vaksin pilihan utamanya.

Farah (22 tahun) memilih vaksin Sinovac karena ketersediaanya. Menurutnya, vaksin preferensinya adalah Pfizer karena ia mendapatkan informasi di media sosial bahwa tingkat effikasinya lebih tinggi dari jenis vaksin yang lain. Namun, karena vaksin jenis itu belum tersedia di Makassar pada waktu itu, maka ia dengan terpaksa mau divaksin dengan jenis vaksin Sinovac karena takut terinfeksi Covid-19. Walaupun jenis vaksinnya Sinovac, Farah tetap percaya bahwa vaksin dapat melindunginya dari serangan virus Covid-19.

\section{Astra Zeneca}

Jika vaksin Sinovac terbuat dari inactivated virus, maka vaksin Astra Zeneca dibuat dari hasil 
rekayasa genetika (viral vector) dari virus flu biasa yang tidak berbahaya. Berdasarkan hasil uji klinis, WHO juga telah menyatakan bahwa Astra Zeneca dinilai efektif untuk melindungi masyarakat dari risiko Covid-19 yang sangat serius, seperti rawat inap, penyakit parah, hingga mencegah kematian, dengan tingkat efikasi antara 63\% dan $75 \% .{ }^{15}$ Vaksin Covid-19 buatan perusahaan farmasi Inggris Astra Zeneca ini mendapatkan izin penggunaan darurat dari Badan POM pada tanggal 22 Februari 2021.

Efek samping yang umum terjadi setelah mendapatkan vaksin Astra Zeneca, antara lain nyeri, memar pada bagian yang disuntik, demam, menggigil, kelelahan, sakit kepala, mual, nyeri sendi dan otot, hingga yang lebih serius, seperti muntah, diare atau penggumpalan darah.

Menurut informasi yang diperoleh di media sosial bahwa jenis vaksin Astra Zeneca $70 \%$ dan lebih efektif dibandingkan dengan jenis vaksin Sinovac. Itulah yang membuat Inan (22 tahun) memilih jenis vaksin Astra Zeneca. Inan mengakui bahwa jenis vaksin tersebut sangat bereaksi terhadap tubuhnya karena ia mengalami demam selama seminggu. Tapi dengan reaksi yang seperti itu, ia justru memiliki keyakinan bahwa semakin keras efek samping suatu vaksin, maka efikasinya juga semakin tinggi, sehingga potensinya untuk terinfeksi Covid-19 juga semakin kecil.

Abian (21 tahun) memilih jenis vaksin Astra Zeneca karena merupakan vaksin buatan dari Inggris dengan tingkat efikasi $70 \%$. Sedangakan jenis vaksin Sinovac buatan dari Cina dengan tingkat efikasi yang lebih rendah (65\%). Sebelum memilih jenis vaksinasi, ia terlebih dahulu mencari informasi di media-

\footnotetext{
${ }^{15}$ https://homecare24.id/2021/09/02/perbedaanvaksin-sinovac-astrazeneca-pfizer-moderna/, diakses tanggal 25 Novermber 2021.
}

media sosial terkait jenis-jenis vaksin Covid-19, asalnya, dan tingkat efikasinya.

Dari berbagai informasi tentang jenisjenis vaksin yang diperolehnya, termasuk dari media sosial, Lisa (20 tahun) membandingkan tingkat efikasi dan efek samping kemungkinan muncul setelah divaksinasi. la kemudian memilih jenis vaksin Astra Zeneca karena efektivitasnya lebih tinggi dibandingkan Sinovac, meskipun dengan efek samping yang lebih keras. Setelah divaksin, ia mengalami demam selama tiga hari. Baginya ini tidak apa-apa dibandingkan efek yang dialami oleh orang lain yang juga memakai vaksin sama.

\section{Moderna}

Vaksin Moderna merupakan jenis vaksin mRNA (messenger RNA). Berbeda dari Sinovac yang menggunakan virus yang dilemahkan atau dimatikan, Moderna menggunakan komponen materi genetik yang membuat sistem kekebalan tubuh memproduksi spike protein, protein yang merupakan merupakan bagian dari permukaan virus Corona. Setelah melalui uji klinis fase ketiga, vaksin jenis ini mendapatkan izin penggunaan darurat dari badan POM pada tanggal 2 Juli 2021 dengan tingkat efikasi sebesar $94,1 \%$ pada kelompok usia antara 18 dan 65 tahun. Efikasinya kemudian menurun menjadi $86,4 \%$ untuk usia di atas 65 tahun. Berdasarkan hasil uji klinis juga menunjukkan bahwa vaksin Moderna aman untuk kelompok populasi masyarakat dengan komorbid atau penyakit penyerta, seperti penyakit paru kronis, jantung, obesitas berat, diabetes, penyakit lever hati, dan HIV.

Vaksin Moderna awalnya hanya diperuntukkan bagi kalangan terbatas. Namun, kini masyarakat umum bisa menggunakan jenis vaksin ini. Kintan (21 tahun) mendapatkan informasi dari internet bahwa jenis vaksin Moderna memiliki tingkat efikasi yang tinggi 
$(94,5 \%)$, sehingga Kintan memilih jenis vaksin ini untuk mendapatkan efikasi imunitas yang tinggi pada tubuhnya agar lebih tangguh terhadap Covid-19 mengingat bahwa varian Covid-19 juga semakin banyak.

Berdasarkan informasi yang diperoleh Memei (29 tahun) dari media sosial, bahwa vaksin Moderna memiliki tingkat efikasi yang lebih tinggi dari Sinovac, maka ia memilih jenis vaksin tersebut, meskipun ia mengetahui bahwa efek sampingnya lebih keras dibandingkan efek samping vaksin jenis lain. Setelah divaksinasi, ia mengalami bercak-bercak merah di seluruh badan, nafsu makannya meningkat, dan ini berlangsung selama dua minggu.

Meskipun vaksin Sinovac sangat populer di Indonesia, namun sejak awal dicanangkannya program vaksinasi dan munculnya berbagai jenis vaksinasi, Markonah (24 tahun) lebih memilih jenis vaksin Moderna karena ia sudah membaca informasi dari internet jenis Moderna memiliki tingkat efikasi yang lebih tinggi dibandingkan dengan jenis vaksin lain. la tidak bergeming, mekipun ia juga mengetahui bahwa efek sampingnya juga lebih tinggi dibandingkan dengan jenis vaksin lainnya. Pasca vaksin ia mengalami demam selama lima hari.

Jika membandingka ketiga vaksin di atas, maka jenis vaksin yang memiliki tingkat efikasi yang paling tinggi adalah Moderna. Tapi pilihan tidak selamanya berkelindan dengan level efikasi karena ada pertimbangan lain yang dijadikan sebagai dasar untuk mengambil keputusan tentang jenis vaksin yang ingin digunakan (seperti efek samping dari vaksin, dll.), sehingga Sinovac yang memiliki tingkat efikasi terendah dibandingkan dengan jenis vaksin yang lain menjadi pilihan banyak orang. Bagi mereka yang memilih vaksin tertentu karena tingkat efikasinya, maka efek samping yang dirasakan tidak menjadi masalah karena ada harapan yang terkait dengan tingkat efikasi yang tinggi. Artinya ada keseimbangan antara efek samping dan efikasinya (baca, misalnya, Idrus dan Hyman 2014).

\section{Kesimpulan dan Rekomendasi}

Pemerintah berupaya untuk menanggulangi penyebaran Covid-19, salah satunya dengan program vaksinasi. Namun, program yang dicanangkan oleh pemerintah ini menimbulkan perdebatan, ada yang setuju dan ada yang menolak dengan berbagai alasan.

Mereka yang menyatakan menyetujui untuk divaksin karena melihat dari sisi manfaat, ingin mewujudkan tujuan pemerintah untuk mencapai herd immunity, dan karena percaya bahwa program vaksinasi yang dicanangkan pemerintah sebagai bentuk perlindungan negara terhadap rakyatnya. Adapun mereka yang tidak setuju divaksinasi karena mereka masih memercayai informasi yang beredar di lingkungan sekitar bahwa vaksin itu berdampak buruk bagi tubuh, percaya diri terhadap sistem imun yang dimiliki, menganggap bahwa vaksin sangat tidak efektif untuk mencegah penularan Covid-19, dan belum sepenuhnya percaya kepada program pemerintah.

Tiga jenis vaksin yang populer di Indonesia yaitu Sinovac, Moderna, dan Astra Zeneca. Jenis vaksin yang paling banyak digunakan di Indonesia adalah vaksin jenis Sinovac karena tiga alasan. Pertama, karena ini merupakan vaksin yang pertama muncul di Indonesia. Kedua, karena efek sampingnya yang relatif ringan. Ketiga, meskipun tingkat efikasinya rendah (65\%), ini seimbang dengan efek sampingnya.

Masyarakat umumnya tidak mengetahui mana informasi benar dan mana informasi yang hoaks, sehingga informasi yang diperoleh masyarakat diterima begitu saja. Banyak informasi negatif tentang vaksian Covid-19 yang disebarkan ke masyarakat melalui media-media 
sosial dan itu memengaruhi mereka dalam perdebatan terkait, bagaimana mereka memersepsikan vaksin Covid-19, dan kenapa mereka memilih vaksin tertentu. Oleh karena itu, masyarakat masih perlu diedukasi tentang vaksin dan jenisnya, tingkat efikasinya, efek sampingnya agar masyarakat mendapatkan informasi yang benar. Selain itu, masyarakat juga perlu diedukasi tentang bagaimana mengetahui suatu berita atau informasi yang diperoleh di media-media sosial/ internet sebagai informasi yang benar atau hoaks.

\section{Daftar Pustaka}

Ali, M.; Sulistyowati, E.; dan Ronabody, I. 2021. "Perlindungan Hukum Atas Vaksisn Covid-19 Dan Tanggung Jawab Negara Pemenuhan Vaksin Dalam Mewujudkan Negara Kesejahtaraan", Jurnal IImu Hukum, Januari, 17(1):35-47, https://www.researchgate.net/publicati on/348908829, diakses tanggal 26 November 2021.

Andriadi.; Agustiarasari, B.P.; Dianto.; Monica, D.; Jordan, M.; Risky,M.; Arsika, P.; Syari, R.; Nursapitri, R.; dan Salmawati. 2021. "Pentingnya Pengenalan Vaksin Di Masa Pandemi Covid-19 Desa Ibul Kecamatan Simpang Teritip", Jurnal Abdimas Bina Bangsa, Juli, 02(01):100104, http://www.jabb.Ippmbinabangsa.id/in dex.php/jabb/article/view/87/62, diakses tanggal 27 November 2021.

Fatima, S.; Harsan, T.; dan Murtiningsih, I. 2021. "Pendidikan Hukum Dalam Sosialisasi Vaksinasi Sebagai Upaya Penanggulangan Penyebaran Covid-19 Di Desa Jagan, Bandosari, Sukohardjo", Jurnal Pengabdian Masyarakat Madani, Agustus, 1(1):75-82, https://doi.org/10.51805/ipmm.v1i1.15, diakses tanggal 26 November 2021.

Gurning, F.P.; Siagian, L.K.; Wiranti, I.; Devi, S.; dan Atika, W. 2021. "Kebijakan Pelaksanaan Vaksinasi Covid-19 Di Kota Medan Tahun 2020", Jurnal Kesehatan, Mei, 10(1):43-50, https://doi.org/10.37048/kesehatan.v1 0i1.326, diakses tanggal 16 November 2021.

Idrus, N. I., dan Hyman, T. D. 2014. "Balancing Benefit and Harm : Chemical Use and Bodily Transformation among Indonesia's Transgender Waria", International Journal of Drug Policy, 25(4):789-797, https://www.sciencedirect.com/science Larticle/pii/S0955395914001637, diakses tanggal 5 Maret 2020.

Kementerian Kesehatan RI. 2021. Keputusan Menteri Kesehatan No. HK.01.07/MENKES/4638/2021 "Tentang Petunjuk Teknis Pelaksanaan Vaksinasi Dalam Rangka Penanggulangan Pandemi Covid-19", Kementerian Kesehatan RI, Mei, 1-157, https://peraturan.bpk.go.id/Home/Deta ils/171640/keputusan-menkes-nohk0107menkes46382021, diakses tanggal 26 November 2021.

Makmun, A.; Hazyhiyah, F.S. 2020. "Tinjauan Terkait Pengembangan Vaksin Covid19", Jurnal Molucca Medica, Oktober, 13(2):52-59, https://doi.org/10.30598/molmed.2020 .v13.i2.52, diakses tanggal 16 November 2021.

Nugroho, S.A. dan Hidayat I.N. 2021. "Efektivitas Dan Keamanan Vaksin Covid-19 : Studi Referensi", Jurnal Keperawatan 
Profesional, Agustus, 9(2):1-47.

Puteri, K.E.; Wiranti, K.; Ziliwu, Y.S.; Elvia, S.; Frare, D.Y.; Purdani, R.S.; dan Niman, S. 2021. "Kecemasan Masyarakat akan Vaksinasi Covid-19", Jurnal Keperawatan Jiwa, 9(3):539-548, https://jurnal.unimus.ac.id/index.php/J $\mathrm{KJ} /$ article/view/7794/pdf, diakses tanggal 15 September 2021.

Rachman, F.F. dan Pramana, S. 2020. "Analisis Sentimen Pro dan Kontra Masyarakat Indonesia tentang Vaksin COVID-19 pada Media Sosial Twitter", Desember, 8(2):100-109.

https://inohim.esaunggul.ac.id/index.ph p/INO/article/view/223/0, diakses tanggal 17 Agustus 2021.

Rahayu, R.N. dan Sensusiyati. 2021. "Vaksin Covid-19 Di Indonesia: Analisis Berita Hoax", Jurnal Ekonomi, Sosial, dan
Humaniora, Februari 9(2):39-49.

Sukmana, R.A.; Iyansyah, M.I.; Wijaya, B.A.; dan Kurniawati, M.F. 2021. "Implementasi Strategi Komunikasi Kesehatan dalam Meyakinkan Masyarakat untuk Pelaksanaan Vaksinasi COVID-19 di Kabupaten Barito Kuala", Jurnal Sains Sosio Humaniora, Juni, 5(1):409-419, https://doi.org/10.22437/jssh.v5i1.1415 3, diakses tanggal 16 November 2021.

Valerisha, A.; dan Putra, M.A. 2020. "Pandemi Global Covid-19 Dan Problematika Negara-Bangsa: Transparansi Data Sebagai Vaksin Socio-Digital?", Jurnal Ilmiah Hubungan Internasional, Oktober, $\quad$ 0(0):131-137, https://doi.org/10.26593/jihi.v0i0.3871. 131-137, diakses tanggal 16 November 2021. 